\title{
Screening of Antagonistic Activity of Lactic Acid Bacteria Strains in relation to Candida scotti for Optimal Conservation of Plant Juices
}

\author{
Ravilya A. Shurkhno (Corresponding author) \\ JSC Tatarstan Scientific and Production Association BioAgro \\ Cheluskin str., 28, Kazan, 420127, Russia \\ E-mail: Ravillya@yandex.ru
}

Shamil Z. Validov

Kazan (Volga-Region) Federal University

Kremlevskaya str., 18, Kazan, 420008, Russia

E-mail: SZValidov@kpfu.ru

Olga N. Ilinskaya

Kazan (Volga-Region) Federal University

Kremlevskaya str., 18, Kazan, 420008, Russia

E-mail: ilinskaya_kfu@mail.ru

Received: April 13, 2014 Accepted: April 27, 2014

doi:10.5296/jas.v2i2.5471 URL: http://dx.doi.org/10.5296/jas.v2i2.5471

\begin{abstract}
In a model experiment on juices of legumes with nine strains of lactic acid bacteria (LAB) of the genus Lactobacillus isolated from aboveground parts of the vegetating leguminous plants (RS1, RS3, RS4), their rhizosphere (RS5), plant juices (RS6 and RS7), and a corn silage (RS2), and also with the collection strain of Lactobacillus plantarum BS933 and commercial strain Streptococcus faecium 500, joint cultivation with Candida scotti was carried out. Change of standard indicators, such as $\mathrm{PH}$ of the medium, the ratio of lactic acid to fatty acid homologues, and microflora analysis of the juice demonstrated that yeast actively competes with LAB for nutrients in the environment and possesses an antibacterial effect that leads to silage deterioration. The results showed that only certain Lactobacillus strains (3 of 8) and also $S$. faecium 500 are capable of resisting negative consequences of yeast activity during
\end{abstract}


conservation of plant juices.

Keywords: Plant juice, Yeast, Lactic acid bacteria, Fermentation, Clover, Galega, Alfalfa

\section{Introduction}

Silage preparation as way of preserving juicy forages was developed long time ago (Acosta Aragon et al., 2012). The study of the difficult microbiological and biochemical mechanisms which are responsible for the process of fermentation began to be carried out only in the second half of the twentieth century (Danner et al., 2003; McDonald et al., 1991). In this regard, many questions remain unresolved, including the role of accompanying yeast cultures at a fermentation of plant substrates by epiphytic bacteria.

It is known that ensilage is accompanied by yeast activity, which can have a negative impact on the quality of silage of plant masses (Broberg et al., 2007). Yeast activity in silage is considered undesirable for two reasons: intensive reproduction of yeast upon transition to aerobic conditions is accompanied by creation of an favourable environment for growth of putrefactive bacteria and fungi; and the competition of yeast with lactic acid bacteria (LAB) for sugars in fermentation leads to formation of ethanol, which is undesirable in siloing (Dolci et al., 2011; Gobbetti et al., 1994; Kitamoto et al., 1999).

The absence of researcher's attention to functional activity of yeast was connected with the underestimation of their role owing to their small number in fodder plant mass. However, modern research proved a contribution of yeasts to conservation of green forages (McDonald et al., 1985). So, in certain conditions the yeast quantity can significantly increase and reach the number surpassing 105 organisms on $1 \mathrm{~g}$ of a stern weight (McDonald et al., 1985). It is known that the inhibition of yeast in silage is caused by their inability to proliferate actively in the conditions of the low redox potential created by LAB (Ohmomo et al., 1993). At the same time, growth of yeast is not suppressed with acidity of the environment; in fact, some strains are capable of surviving at PH 2.0 and even below (McDonald et al., 1985).

In specific ecological conditions, the certain relationship between different groups of microorganisms depends on their physiological features (Egorov, 1994). Generally, this relationship can be subdivided conditionally into favourable (synergism) and adverse (antagonism). However, difficult and variable relationships between microbial communities do not always fit within the framework of these divisions.

Specific features of LAB play an essential role in the relationship between LAB and yeast in plant mass (Kitamoto et al., 1993). Application of LAB gives the greatest effect by conservation of the high-protein leguminous plants and improves the quality of silage (McDonald et al., 1993). It was established that application of selective races of microorganisms, as a rule, possesses a number of advantages in comparison with native microflora (McDonald et al., 1985).

Introduction of homofermentative lactic acid bacteria to plant mass will cause better conservation and enrichment by nutritious components, especially amino acids and the vitamins synthesised by microorganisms. Then, it will lead to the increased availability of silage for animals (Dogi et al., 2013). The goal of this work was to study the influence of various strains of LAB on Candida scotti during joint cultivation in plant juices, to identify the most effective strains of LAB and to optimise fermentation of plant substrates. 


\section{Research Methods}

\subsection{Samples}

Leguminous grasses used in experiments were: a red clover (Trifolium pratense) grade Early-2, a fodder galega (Galega orientalis) grade Gale, and an Alfalfa changeable (Medicago varia Martyn) grade Ayslu.

\subsection{Plant Juices}

The aboveground plant parts (leaves with petioles and stem fragments) were minced $(2-3 \mathrm{~cm})$ and squeezed with a press. The plant mass was filtered three times through a sterile cloth to centrifuge the resulting juice (5000 g, $10 \mathrm{~min}$ ). The supernatant was sterilised by membrane filtration $(0.45 \mu \mathrm{m}$ pore diameter, Millipore, United States), poured into sterile containers, and stored frozen until used (Christiansson et al., 1997).

\subsection{Microorganisms, Cultivation Conditions, and Counts}

LAB strains isolated from aboveground parts of vegetating leguminous plants (RS1, RS3, RS4), their rhizospheres (RS5), plant juices (RS6 and RS7), and a corn silage (RS2), were characterised in our previous work (Shurkhno et al., 2005). Lactobacillus plantarum BS933 (Kozlova et al., 1999) and Candida scotti was obtained from the collection of the Institute of Biochemistry and Physiology of Microorganisms (Puschino, Russia), Streptococcus faecium 500 was obtained from the collection of Russian Institute of Agricultural Microbiology (St. Petersburg, Russia). All bacteria were cultivated on selective Rogosa medium ( $\mathrm{pH}$ 5.5) (Rogosa et al., 1951) at $37^{\circ} \mathrm{C}$ in stationary conditions without aeration. Yeasts were cultivated on Saburo medium (Egorov, 1995). LAB and yeasts were counted after cultivation on agar media (Zvyagintsev, 1991; Pimenova et al., 1971; Tepper et al., 2004). The number of microorganisms was expressed in colony-forming units (CFU) per $\mathrm{ml}$ of juice (Egorov, 1995; Tepper et al., 2004).

\subsection{Fermentation of Plant Juices}

Tubes containing $5 \mathrm{ml}$ juice of legumes (galega, clover, or alfalfa) were inoculated with 0.5 $\mathrm{ml}$ of LAB cultures $(1-3 \times 105$ cells $/ \mathrm{ml})$ grown $18 \mathrm{~h}$ in MRS medium at $37^{\circ} \mathrm{C}$ (Netrusov et al., $2006)$, and with $0.5 \mathrm{ml}$ of yeast culture $(3-4 \times 102$ cell $/ \mathrm{ml})$ grown in liquid Saburo medium at $28^{\circ} \mathrm{C}$ (Egorov, 1995).

Counts of $\mathrm{LAB}$ and yeasts were performed directly during fermentation of plant juice, upon aseptic sampling at the beginning of the experiment and on days 3, 10, 20, 30, and 45 by plating serial dilutions onto agar Rogosa and Saburo media, respectively. Cultivation was performed at room temperature, imitating of production conditions. Each plant juice was fermented in triplicate.

\subsection{Physical and Chemical Indicators}

Dry matter was determined in plant mass by drying at $105 \pm 2^{\circ} \mathrm{C}$ (GOST 27548). Total nitrogen was assayed by the Kjeldahl method by burning organic substances in concentrated $\mathrm{H}_{2} \mathrm{SO}_{4}$ with formation of ammonium salts and quantitative accounting ammonia by a titrimetric method after distillation. The analysis was carried out in an automatic mode (VELP Scientifica, Italy), which consisted of a digester for wet combustion (DK-6) and a fully automatic distillation device with a built-in titrator (UDK-152). The content of nitrogen in the studied material, with subsequent recalculation of the total nitrogen, was estimated in 
accordance with GOST13496.4.

\subsection{Chemical Methods}

Active acidity of plant juice was determined by a Meter Toledo MP-120 (Germany) pH meter (Gerhard, 1984).

\subsubsection{Carbohydrate Composition}

Plant juices were assayed by high-performance liquid chromatography (HPLC) in a Perkin Elmer Series-200 device (United States) equipped with a SUPELCOGEL Pb column $(300 \times 7.8 \mathrm{~mm})$ and a refractive index detector. Ultrapure water (Direct-Q system, Millipore) was used for elution. The rate of the mobile phase was $0.5 \mathrm{ml} / \mathrm{min}$; temperature was $80^{\circ} \mathrm{C}$. The samples were prepared using SerPak C-18 cartridges (TESSEK Ltd, Czech Republic) filled with Separon SGXC18 sorbent (particle size, $60 \mu \mathrm{m}$; diameter, 80 A) for removal of high-molecular-weight compounds and pigment substances.

\subsubsection{Organic Acids}

Organic acids were analyzed using a Perkin Elmer Series-200 (United States) HPLC chromatograph equipped with a column $(250 \times 4.6 \mathrm{~mm})$ and a refractive index detector. $\mathrm{H}_{3} \mathrm{PO}_{4}$ $(0.1 \%)$ was used for elution. Elution flow rate was $0.6 \mathrm{ml} / \mathrm{min}$; temperature was $30^{\circ} \mathrm{C}$. Aqueous solutions of organic acids, produced by ACROS (Belgium), were used as standards. The samples were prepared using SerPak C-18 cartridges (Ohmomo, S. et al., 1993).

\subsection{Data Analysis}

Statistical processing of results was carried out using the program Microsoft Office Excel 2013.

\section{Results and Discussion}

\subsection{Characteristics of Plant Materials}

Plant mass was characterized according to the content of nitrogen and sugars (Table 1).

Table 1. Characteristic fermentation of plant substances

\begin{tabular}{|c|c|c|c|}
\hline \multirow{2}{*}{ Parameters } & \multicolumn{3}{|c|}{ Chemical composition of plant mass of leguminous crops, g/kg } \\
\cline { 2 - 4 } & galega & clover & alfalfa \\
\hline Dry matter & $349 \pm 63.9$ & $292 \pm 48.2$ & $370 \pm 20.2$ \\
\hline Total nitrogen & $8.8 \pm 2.5$ & $8.0 \pm 1.3$ & $12.7 \pm 0.2$ \\
\hline & \multicolumn{3}{|c|}{ Composition of sugars of plant juice, g/kg } \\
\hline Glucose & $14.9 \pm 0.8$ & $22.5 \pm 1.1$ & $3.7 \pm 0.19$ \\
\hline Fructose & $9.4 \pm 0.6$ & $11.9 \pm 0.6$ & $0.8 \pm 0.04$ \\
\hline Maltose & $1.0 \pm 0.05$ & $1.0 \pm 0.05$ & $0.3 \pm 0.02$ \\
\hline Total sugar & $25.3 \pm 1.3$ & $35.4 \pm 1.8$ & $4.8 \pm 0.2$ \\
\hline
\end{tabular}

\subsection{Cultivation of Microorganisms}

To find the most promising monocultures of LAB in joint cultivation with yeasts, microbiological monitoring was carried out for 45 days. In fermentation of galega and alfalfa juices, counts of nine examined strains of LAB and also $C$. scotti changed depending on fermentation phase. Joint cultivation did not lead to achievement of optimum ensiling 


\section{MInstitute ${ }_{\text {Mnk }}^{\text {Macrothink }}$}

conditions ( $\mathrm{pH} 4-5$ ) or to formation of a significant amount of lactic acid (Table 2, Figure 1). The content of sugars in these substrates was insufficient for a positive result, although the maximum counts of LAB on the $3^{\text {rd }}$ and $10^{\text {th }}$ days reached $2.8 \times 10^{9}$ and $4.0 \times 10^{9} \mathrm{CFU} / \mathrm{ml}$, respectively with galega juice, and $1.7 \times 10^{9}$ and $2.3 \times 10^{9} \mathrm{CFU} / \mathrm{ml}$, respectively with an alfalfa juice. Our previous results showed that the use of LAB monocultures demonstrate a high degree of ensilage of galega, but not alfalfa (Shurkhno et al., 2006). As raw materials for ensilage, alfalfa has essential shortcomings: it contains high amounts of protein, potassium, calcium, and other substances with an alkaline effect when the sugar content is low (Table 2). In fermentation of clover juice (Figure 1), counts of studied Lactobacillus bacteria on the $3^{\text {rd }}$ and $10^{\text {th }}$ days increased from $2,2 \times 10^{8}$ to $9.9 \times 10^{8} \mathrm{CFU} / \mathrm{ml}$ (RS3), from $4.0 \times 10^{8}$ to $8.8 \times 10^{8}$ $\mathrm{CFU} / \mathrm{ml}$ (RS6), and from $1.2 \times 10^{8}$ to $9.7 \times 10^{8} \mathrm{CFU} / \mathrm{ml}$ (RS7). Counts of $\mathrm{S}$. faecium 500 decreased from $5.0 \times 10^{8}$ to $2.7 \times 10^{8} \mathrm{CFU} / \mathrm{ml}$. The quantity of LAB in this time interval of fermentation exceeded the content of yeasts by 1.3 and 2.5 times in case of strain RS3, by 1.7 and 1.3 times for RS6, by 1.5and 3.2 times for RS7, and by 1.4 and 1.8 times for S. faecium 500. The results showed that the physiological-biochemical potential of these four strains allowed effective realisation of the technological process of clover ensilage. Five other strains of Lactobacillus, RS1, RS2, RS4, RS5, and L. plantarum BS933 (Table 2), did not show the biochemical activity necessary for conservation. Important criteria of an assessment of LAB used for ensilage are $\mathrm{PH}$ of the medium and concentration of organic acids. It is known, that microbial inoculation of plant mass with $L$. plantarum improved fermentation and composition of silage (Kung et al., 2006). As it was shown by Taylor et al. (Kung et al., 2002), inoculation with L. buchneri decreased the final concentrations of lactic acid but increased concentrations of acetic acid and ethanol in silage from laboratory and farm silos, and can improve the aerobic stability of barley silage. Our data demonstrated increased concentration of lactic acid in Lactobacilli-treated plant juices (Figure 2), that has favorable effect for future application of Lactobacillus RS3, RS6, RS7 and S. faecium 500 in silage fermentation.

Table 2. PH values at fermentation of plant juices the various strains of lactic acid bacteria and yeast

\begin{tabular}{|c|c|c|c|c|c|}
\hline \multirow{2}{*}{ № } & \multirow{2}{*}{ Strains, LAB } & \multirow{2}{*}{ Time, day } & \multicolumn{3}{|c|}{ Species } \\
\hline & & & clover & galega & alfalfa \\
\hline \multirow{2}{*}{1.} & \multirow{2}{*}{ Lactobacillus RS1 } & 0 & 6.15 & 6.20 & 6.12 \\
\hline & & 45 & 8.23 & 8.54 & 8.74 \\
\hline \multirow{2}{*}{2.} & \multirow{2}{*}{ Lactobacillus RS2 } & 0 & 6.15 & 6.20 & 6.12 \\
\hline & & 45 & 8.70 & 8.57 & 8.61 \\
\hline \multirow{2}{*}{3.} & \multirow{2}{*}{ Lactobacillus RS3 } & 0 & 6.15 & 6.20 & 6.12 \\
\hline & & 45 & 4.47 & 8.62 & 8.53 \\
\hline \multirow{2}{*}{4.} & \multirow{2}{*}{ Lactobacillus RS4 } & 0 & 6.15 & 6.20 & 6.12 \\
\hline & & 45 & 8.54 & 8.70 & 8.57 \\
\hline \multirow{2}{*}{5.} & \multirow{2}{*}{ Lactobacillus RS5 } & 0 & 6.15 & 6.20 & 6.12 \\
\hline & & 45 & 8.65 & 8.62 & 8.66 \\
\hline \multirow{2}{*}{6.} & \multirow{2}{*}{ Lactobacillus RS6 } & 0 & 6.15 & 6.20 & 6.12 \\
\hline & & 45 & 4.28 & 8.71 & 8.50 \\
\hline \multirow{2}{*}{7.} & \multirow{2}{*}{ Lactobacillus RS7 } & 0 & 6.15 & 6.20 & 6.12 \\
\hline & & 45 & 4.88 & 8.61 & 8.49 \\
\hline \multirow{2}{*}{8.} & \multirow{2}{*}{$\begin{array}{c}\text { Lactobacillus plantarum } \\
\text { BS933 }\end{array}$} & 0 & 6.15 & 6.20 & 6.12 \\
\hline & & 45 & 8.60 & 8.73 & 8.65 \\
\hline \multirow{2}{*}{9.} & \multirow{2}{*}{ Streptococcus faecium 500} & 0 & 6.15 & 6.20 & 6.12 \\
\hline & & 45 & 4.34 & 8.40 & 8.54 \\
\hline
\end{tabular}



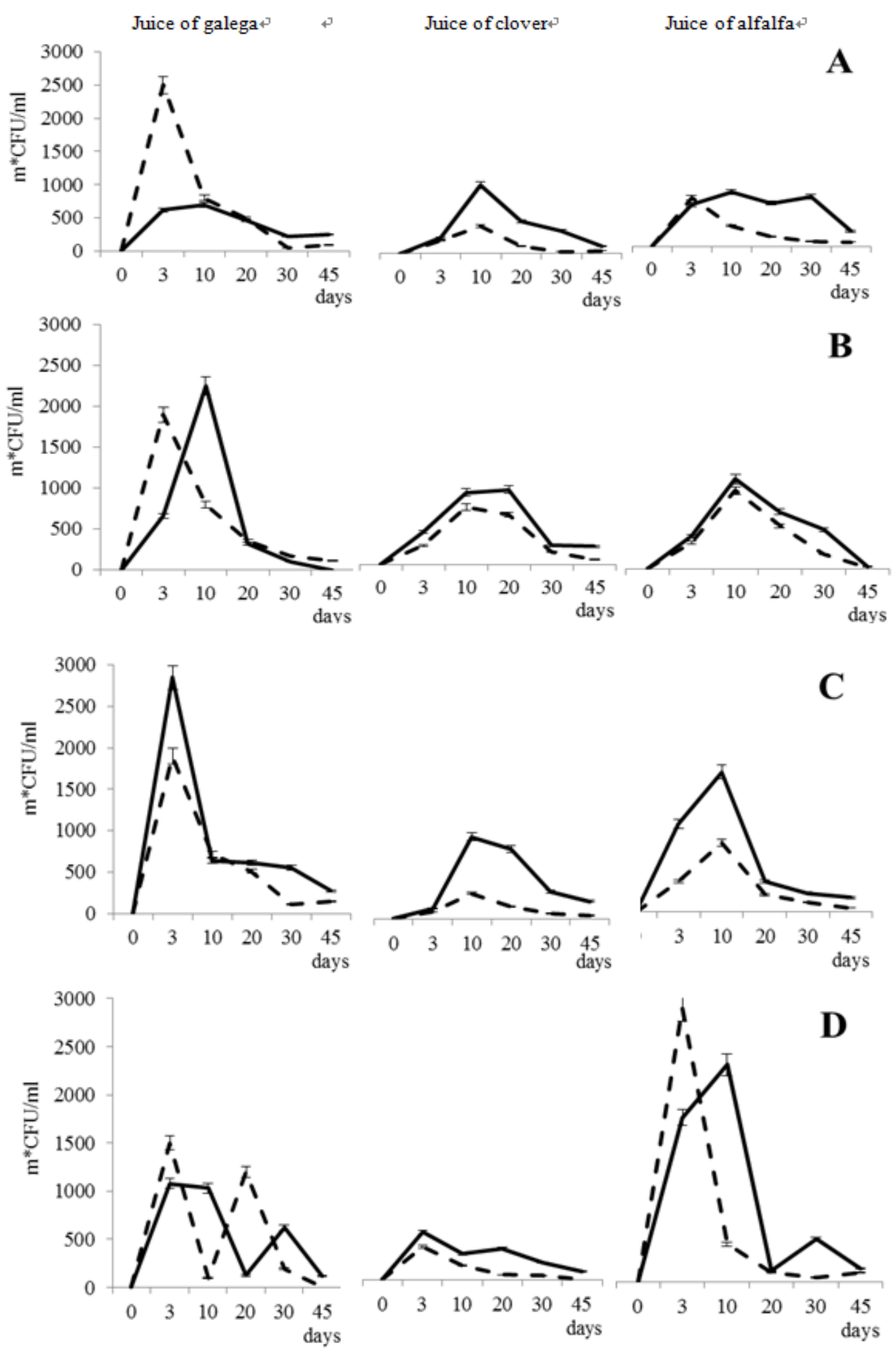

Figure1. Counts lactic acid bacteria and yeasts during fermentation of plant juices of leguminous crops

(—Lactobacillus: A - RS 3, B - L. RS 6, C - L. RS 7; D - S. faecium 500; - - yeast C. scotti). 


\subsection{Change in PH of The Medium During the Experiment}

The $\mathrm{pH}$ values of fresh plant juices were comparable: juice of galega, 6.2; juice of clover, 6.15; and juice of alfalfa, 6.12. The indicator of active acidity of the medium is one of the important criteria of ensilage quality. However, after 45 days of joint cultivation of all studied LAB and yeast, the PH of the juice of galega (Table 2) was alkaline: from 8.40 to 8.73 . Similar results were observed with juice of alfalfa (Table 2), whose $\mathrm{pH}$ range from 8.49 to 8.74. It is possible that in these conditions, yeast utilises plant proteins, with formation of ammonium causing medium alkalisation.

As for juice of clover (Table 2), RS1, RS2, RS4, RS5, and L. plantarum BS933 caused medium alkalisation in the course of fermentation ( $\mathrm{pH} 8.23-8.70)$. Only in case of Lactobacillus RS3, RS6, and RS7 and S. faecium 500 did the active acidity of the medium respond to the demand; $\mathrm{pH}$ values were $4.47,4.28,4.88$, and 4.34 , respectively.

\subsection{Analysis of Products of Fermentation}

Analysis of the content of lactic, acetic, and propionic acids at the end of fermentation of juice of galega showed that the greatest quantity of acids was formed by Lactobacillus RS1 strains $(0.82 / 0.76 / 0.72 \mathrm{mg} / \mathrm{ml}$ of plant juice, respectively), RS7 strains $(0.59 / 0.85 \mathrm{mg} / \mathrm{ml}$ of plant juice), and RS2 (0.53/0.32 mg/ml of plant juice; Figure 2A). However, such contents did not lead to the needed acidulation of the medium owing to the growth of $C$. scotti, which interfered with LAB during substrates fermentation and changed the necessary direction of biochemical processes. Identical results were observed with alfalfa juice of (Figure 2B), for which bad ensiling was also proven (Shurkhno et al., 2006). Unlike the two juices considered above, the maximum concentration of lactic and acetic acids in clover juice were obtained for Lactobacillus RS3 (6.4/0.6 mg/ml), RS6 (8.3/0.8 mg/ml), RS7 (5.4/0.5 mg/ml), and $S$. faecium $500(7.9 / 0.7 \mathrm{mg} / \mathrm{ml})$ (Figure $2 \mathrm{~B})$. The corresponding $\mathrm{PH}$ values of the medium were $4.47,4.28,4.88$, and 4.34, respectively (Table 2). The other five strains of LAB, RS1, RS2, RS4, and RS5, and L. plantarum BS933 produced few organic acids and did not provide the necessary level of active acidity in the medium (Table 2).

It is known that in anaerobic conditions yeasts form acetic, propionic, butyric, and isobutyric acids (McDonald et al., 1985). For this reason, in the fermentation of juice by joint cultivation of LAB and yeast, trace amounts of propionic and butyric acids were found (Figure 2). (Kung et al., 1991) demonstrated that inoculating corn silage with $1 \times 10^{6} \mathrm{CFU} / \mathrm{g}$ of L. buchneri dramatically improved the aerobic stability of corn silage. Moreover, the silage treated with the high $\left(1 \times 10^{6} \mathrm{CFU} / \mathrm{g}\right)$ rate of L. buchneri had an increased concentration of acetic acid (3.60\%) and decreased level of yeasts $(2.01 \log \mathrm{CFU} / \mathrm{g})$. These facts are in accordance with our data concerning juices fermentation quality improvement after treatment with Lactobacillus RS3, RS6, RS7 and S. faecium 500. 

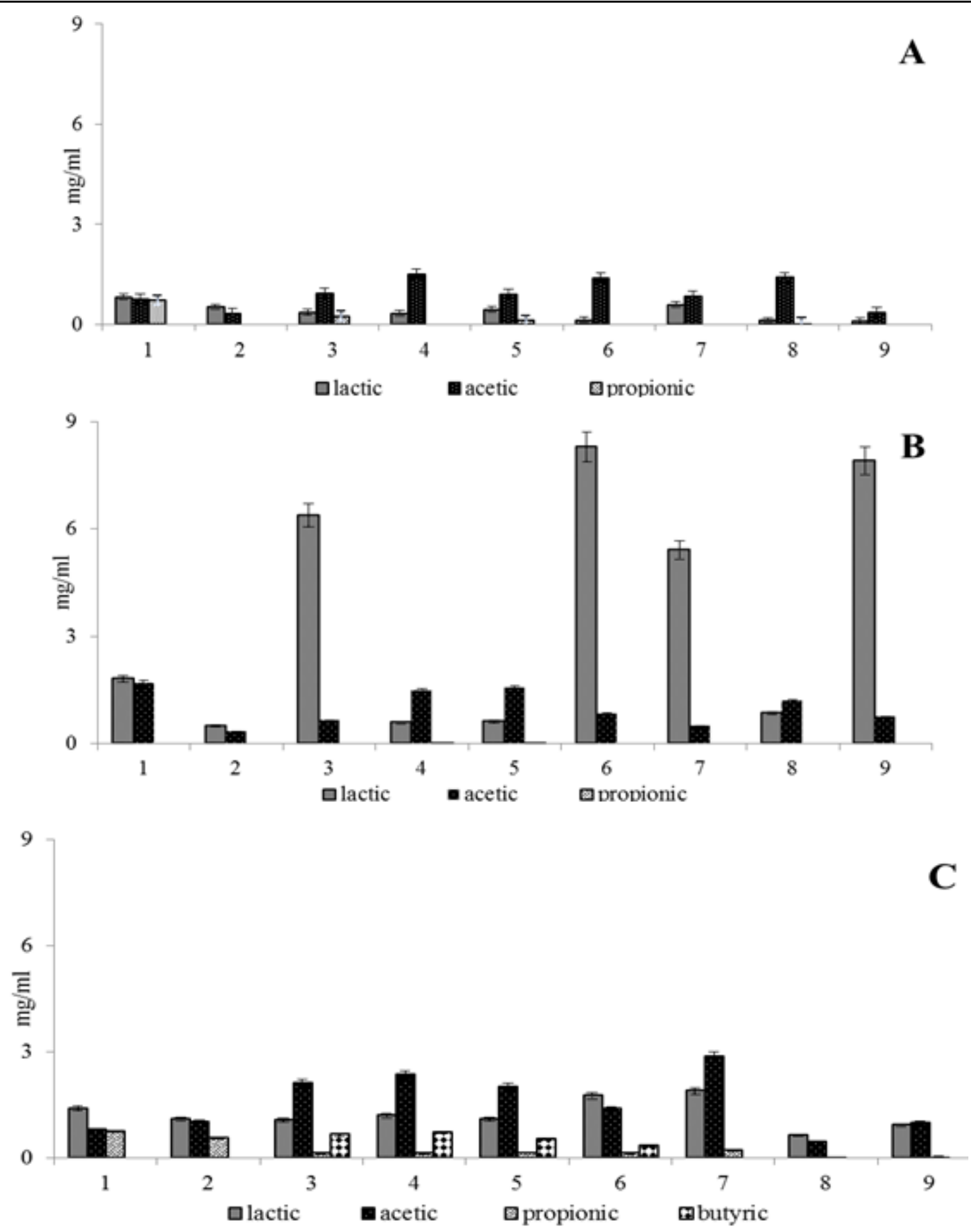

Figure 2. Concentration of organic acids after 45 days of plant juices fermentation of leguminous crops by lactic acid bacteria and yeasts

A - juice of galega, B - juice of clover, C - juice of alfalfa. 1 - L. RS 1; 2 - L. RS 2; 3 - L. RS 3; 4 - L. RS 4; 5 L. RS 5; 6 - L. RS 6; 7 - L. RS 7; 8 - L. plantarum BS 933; 9 - S. faecium 500, and yeast - C. scotti

\section{Conclusions}

The competition of yeasts for nutrients and also their antibacterial effect led to deterioration in the quality of ensilage. Only certain strains of LAB (RS3, RS6, RS7, and S. faecium 500) 
were able to resist this process. Lactobacillus RS3, RS6, and RS7, isolated at unfavourable ecological conditions from phyllosphere of plants characterised by low availability of nutrients and a small quantity of epiphytic microflora, were able to synthesise high concentrations of lactic acid (according to low $\mathrm{pH}$ ) and grow to the levels necessary for good ensilage quality.

The antibacterial effect of yeasts is due to production of a wide range of extracellular metabolites, including proteins, glycoproteins, and low-molecular-weight glycolipids (Hatoum et al., 2012). The most active toxins are produced by yeasts Hansemda, Candida, Kluyveromyces, and by some others (Buzzini et al., 2001). For this reason, when using yeasts in various biotechnological processes it is necessary to consider features of their metabolism.

Our results confirm that the search for effective acid-forming bacteria which can counteract the undesirable activity of yeasts, for creation of biological preparations, have to include the estimation of metabolic features of chosen microorganisms. This approach will allow maintaining and increasing the nutritional value of forages during a long period.

\section{Acknowledgement}

The research was supported by the Russian Government Program for competitive growth of Kazan Federal University.

\section{References}

Acosta Aragon, Y., Jatkauskas, J., \& Vrotniakiene, V. (2012). The Effect of a Silage Inoculant on Silage Quality, Aerobic Stability, and Meat Production on Farm Scale. ISRN Veterinary Science. http://dx.doi.org/10.5402/345927

Broberg, A., Jacobsson, K., Strom, K., \& Schnurer, J. (2007). Metabolite Profiles of Lactic Acid Bacteria in Grass Silage. Journal Applied and Environmental Microbiolog, 73(17). 5547-5552. http://dx.doi.org/10.1128/AEM.02939-06

Buzzini, P., \& Martini, A. (2001). Discrimination between Candida albicans and other pathogenic species of the genus Candida by their differential sensitivities to toxins of a panel of killer yeasts. Journal Clinic Microbiology, 39(9), 3362-3364. http://dx.doi.org/10.1128/JCM.39.9.3362-3364.2001

Christiansson, A., Ekelund, K., \& Ogura, H. (1997). Membrane filtration method for enumeration and isolation of spores of Bacillus cereus from milk. International Dairy Journal, 7(11), 743-748. http://dx.doi.org/10.1016/S0958-6946(97)00085-X

Danner, H., Holzer, M., Mayrhuber, E., \& Braun, R. (2003). Acetic Acid Increases Stability of Silage under Aerobic Conditions. Journal Applied and Environmental Microbiology, 69(1), 562-567. http://dx.doi.org/10.1128/AEM.69.1.562-567.2003

Dogi, C. A., Fochesato, A., Armando, R., Pribull, B., S.de Souza, M. M., Coelho, I. da Silva., A de Melo, D., Dalcero, A., \& Cavaglieri, L. (2013). Selection of lactic acid bacteria to promote an efficient silage fermentation capable of inhibiting the activity of Aspergillus parasiticus and Fusarium gramineraum and mycotoxin production. Journal Applied 
Microbiology, 114(6), 1650-1660. http://dx.doi.org/10.1111/jam.12173

Dolci, P., Tabacco, E., Cocolin, L., \& Borreani, G. (2011). Microbial Dynamics during Aerobic Exposure of Corn Silage Stored under Oxygen Barrier or Polyethylene Films. Journal Applied and Environmental Microbiology, 77(21), 7499-7507. http://dx.doi.org/10.1128/AEM.05050-11

Egorov, N. S. (1994). Basic teaching about antibiotics. Moscow: Moscow State University Press. 512.

Egorov, N. S. (1995). Guide to Practical Works in Microbiology. Moscow: Moscow State University Press. 217.

Gobbetti, M., Corsetti, A., \& Rossi, J. (1994). The sourdough microflora. Interactions between lactic acid bacteria and yeasts: metabolism of carbohydrates. Journal Applied Microbiology Biotechnology, 41(4), 456-460. http://dx.doi.org/10.1007/BF00939035

Hatoum, R., Labrie, S., \& Fliss, I. (2012). Antimicrobial and Probiotic Properties of Yeasts: From Fundamental to Novel Applications. Front Microbiology. [Online] Available: http://dx.doi: 10.3389/fmicb.2012.00421/Front. Microbiol., (December 19, 2012)

Kitamoto, H. K., Hasebe, A., Ohmomo, S., Suto, E. G., Muraki, M., \& Iimura, Y. (1999). Prevention of Aerobic Spoilage of Maize Silage by a Genetically Modified KillerYeast, Kluyveromyces lactis, Defective in the Ability to Grow on Lactic Acid. Journal Applied and Environmental Microbiology, 65(10), 4697-4700.

Kozlova, E. V., Validov, Sh. Z., \& Boronin, A. M. (1999). Using Lactobacillus plantarium strains for ensilage and their monitoring in the silage microbial association. FEMS sixth Symposium on Lactic Acid Bacteria, Holland.

Kung, L. Jr., Tung, R. S., Maciorowski, K.G., Buffum, K., \& Knutsen, K. (1991). Effects of Plant Cell-Wall-Degrading Enzymes and Lactic Acid Bacteria on Silage Fermentation and Composition. Journal of Dairy Science, 74(12), 4284-4296. http://dx.doi.org/10.3168/jds.S0022-0302(91)78623-2

McDonald, P. (1985). Biochemistry of Silage. Moscow: Agropromizdat. p. 272.

McDonald, P., Henderson, N., \& Heron, S. (1991). The biochemistry of silage. (2nd ed.). Marlow, UK: Chalcombe Publications. p. 249.

Methods of General Bacteriology. Ed. by Gerhard, F. M. (1984). Moscow: Mir. (1) p. 56-460

Methods of Soil Microbiology and Biochemistry. Ed. by Zvyagintsev D. G., (1991). Moscow: Moscow State University Press. p. 303.

Netrusov, A. I., \& Kotova, I. B. (2006). Microbiology. Moscow: Academia. p. 352.

Ohmomo, S., Tanaka, O., \& Kitamoto, H. (1993). Analysis of organic acids in silage by high-performance liquid chromatography. Bulletin National Grass Research Institute, 48, 51-56. 
Pimenova, M. N., Grechushkina N. N., \& Azova, L. G. (1971). Guide to Practical Works in Microbiology. Moscow: Moscow State University Press. p. 221.

Rogosa, M., Mitchell, J. A., \& Wiesman, R. F. (1951). A selective medium for isolation and enumeration of oral and fecal lactobacilli. Journal Applied Bacteriology, 62, 132-133.

Shurkhno, R. A., Gareev, R. G., Abulkhanov, A. G., Validov, Sh. Z., Boronin, A. M., \& Naumova, R. P. (2005). Fermentation of High-Protein Plant Biomass by Introduction of Lactic Acid Bacteria. Journal Applied Biochemistry and Microbiology, 41(1), 79-89.

Shurkhno, R. A., Validov, Sh. Z., Boronin, A. M., \& Naumova, R. P. (2006). Modeling of Lactic Acid Fermentation of Leguminous Plant Juices. Journal Applied Biochemistry and Microbiology, 42(2), 229-235.

Taylor, C.C., Ranjit, N.J. Mills, J.A. Neylon, J.M., \& Kung, L. Jr. (2002). The Effect of Treating Whole-Plant Barley with Lactobacillus buchneri 40788 on Silage Fermentation, Aerobic Stability, and Nutritive Value for Dairy Cows. Journal of Dairy Science, 85(7), 1793-1800. http://dx.doi.org/10.3168/jds.S0022-0302(02)74253-7

Tepper, E. Z., Shilnikova, V. K., \& Pereverzeva, G. I. (2004). Practical Works in Microbiology. Moscow: Drofa. p. 256.

\section{Copyright Disclaimer}

Copyright for this article is retained by the author(s), with first publication rights granted to the journal.

This is an open-access article distributed under the terms and conditions of the Creative Commons Attribution license (http://creativecommons.org/licenses/by/3.0/). 